Proceedings of the Seventh Pacific Science Congress

THE organising comnittee proposes to publish the "Proceedings" of the Seventh Pacific Science Con. gress, held in Nev/ Lealand in 1949, in single divisional or in approprigtely grouped divisional volumes, and to offer singl volumes, as well as sets, for sale. No decision con yet be made as to the grouping of these volumed, or of price ; but the following arrangement has ben tentatively suggested. Vol. 1 : general proceedings, narrative, representation, attendance, resarch plan report ; pp. $150 ; 7 s .6 d$. Vol. 2 : geology, geophysics and volcanology; pp. 600; 28s. 6d. Vol. 3 : meteorology and oceanography; pp. 400; 20s. Vol. 4: zoology; pp. 550; 26s. Vol. 5: botany, and soil resources, agriculture and forestry ; pp. 550 ; 26s. (or Vol. 5 : botany ; pp. 250 ; 11s. $6 d$. ; and Vol. 6 : soil resources, etc.; pp. 300 ; 14s. 6d.). Vol. 6 (or 7): anthropology, public health and nutrition, social sciences; pp. $550 ; 26 s$. It will be realized that the larger the initial order for printing, the lower will be the cost of individual volumes; early registration with Secretary-General of the Congress, Box 27 Newmarket, Auckland, S.E.1, will, therefore, ensure a copy being available and will contribute to lowering the cost. It is hoped to complete the printing by March 1950 .

\section{International Scientific Film Association}

THE third International Scientific Film Congress will be held in Brussels during September 30-October 5. At the time dolegations from many countries will meet to disctss progress in various subjects of importance in pelation to the international aspect of scientific films. Sub-committees will be presenting reports on such projects as the establishment of a standard/method for cataloguing and recording information about scientific films and on customs regulgtions in relation to the international exchange of geientific films. In conjunction with the Congress there will be a scientific film festival. This will include four public sessions with films dealing with research, education and scientific documentation. The fourth show will consist of general scientific films. There will be an exhibition of medical films; but the audience will be restricted to those with medical interests, such as doctors and students. In addition to the public shows, there will be four sessions intended for specialists. The fields covered will be research, education, industry and medicine.

The Scientific Film Association of Great Britain is considering the films to be submitted as the British entry in the festival. While the Association has knowledge of most of the major films, it would appreciate information regarding privately produced films which would be suitable for inclusion. Full details should be sent to the office of the Association at 4 Great Russell Street, London, W.C.1.

\section{Institution of Mechanical Engineers: Awards}

Under the Clayton and Manville Bequests the Institution of Mechanical Engineers has recently made the/ollowing awards for postgraduate training or resegreh in mechanical engineering. The awards amoynt in all to more than $£ 2,200$ for the academic yefr 1949-50. Clayton Fellowships, 1949: F. J. Ldwards (Manchester), for research at the University of Manchester on water-turbine draught tubes; Frank Ellis (London), for research at the Imperial College of Science and Tecknology on certain aspects of hot and cold rolling. Clayton Grant, 1949 : R. D. Richardson
(London), for postgraduate study at the University of Cambridge on boundary-layer problems. Manville Scholarship, supplemented by a Clayton Grant : Brian Mills (Birmingham), for research at the University of Birmingham on the flow of gas through poppet-type exhaust valves. Renewal for a further year of Clayton Fellowships: A. J. Barnard (London), for the continuance of his research at the Imperial College of Science and Technology on plant design and the processes for separating industrial gases by liquefaction; J. W. Fitchie (London), for the continuance of his research at the Manchester College of Technology on fatigue properties.

\section{Aslib Conference}

THE twenty-foy th annual conference of Aslib has been arranged for September 9-12 at Ashorne Hill, near Leamington Spa. Aslib has been formed by the amalgamation of the Association of Special Libraries and Information Bureaux and the British Society for International Bibliography, and is grant-aided by H.M. Treasury through the Department of Scientific and Industrial Research. The conference will, as usual, give opportunity for members to discuss various aspects of work in special libraries and information bureaux, including such matters as the selection and preservation of material for business archives, experience in setting up special libraries, correspondence as a source of technical information, problems of dealing with official publications, and the library as a tool of the theatre. Dr. Percy Dunsheath, president-elect, will open the conference.

\section{University of London}

DR. R. O. BGCHANAN has been appointed University professor of geography in the London School of Economis and Political Science; and Dr. Robert Knox/has been appointed University professor of bacteriology in Guy's Hospital Medical School.

The title of professor of bacteriology has been conferred on Dr. F. R. Selbie in respect of the post held by him in Middlesex Hospital Medical School.

Dr. H. N. Rydon has been appointed reader in organic chemistry in the Imperial College of Science and Technology, and Dr. Sidnie M. Manton, reader in zoology in King's College.

\section{Announcements}

AN International Anatomical Congress will be held in Oxford during July 25-28, 1950, under the presidency of Prof. W. E. Le Gros Clark.

THE Racing Pigeon (19 Doughty Street, London, W.C.I) Is attempting to collect information on the homing instinct in racing pigeons and other birds, and would be glad if anyone who has made experiments in this field would communicate with the editor of that journal.

A National Congress of Fruit-Growing will be held 7 Ferrara, Italy, during October 9-16; there wil also be an exhibition of autumn- and wintermaturing fruits with pomological classification. All those interested are welcome to attend this meeting, and papers are invited (in triplicate) for the bibliographical section of the Congress. All foreign participants will be granted facilities during their stay in Italy, and there will be, free of charge, several excursions in the country. Further information may be obtained from the Secretary of the Third National Congress of Fruit-Growing, Foreign Section, Via Salita Castello 10, Ferrara, Italy. 